\title{
Assessing the impact of teleworking on employees' labor productivity and effectiveness of entity in the period of COVID-19
}

\section{Muyassarzoda FAYZIEVA ${ }^{1}$, Sanjar GOYIPNAZAROV ${ }^{2}$, Gulnora ABDURAKHMANOVA ${ }^{3}$}

Binary Graduate School, Tashkent Institute of Finance

\section{ARTICLE INFO}

\section{Article history:}

Received September 2020

Received in revised form

15 September 2020

Accepted 15 October 2020

Available online

30 October 2020

\section{Keywords:}

teleworking

Covid-19

labor productivity

employee performance

effectiveness of entity

\begin{abstract}
This paper examines the impact of teleworking on employees' labor productivity and the entity's management in the condition of global pandemic Covid-19 in Uzbekistan. The epidemiological and dynamic nature of the Covid-19 crisis in which organizations have to adopt a work-from-home policy made this investigation very necessary. When the issue is explained more broadly, this empirical research investigates two significant aspects about teleworking process in organizations in the period of lockdown in Uzbekistan. First, teleworking positively affects employee' labour productivity and the effectiveness of the entity, and the second teleworking complicates the management activities and affects negatively the socio-emotional environment in the work team. The objectives of the study are to identify whether the process of telework affects positively or negatively the organization's current labour processes and propose multiple recommendations regarding to improve the telework mechanism for enabling prospective labour concerns in the human resources field of Uzbekistan. To achieve the objectives, a survey research design was adopted. The techniques employed in analyzing the data were quantitative methodology, descriptive statistics and Pearson's correlation coefficient. The results indicated that working from the home policy has a strong and positive relationship with employee' labour productivity and the effectiveness of the entity if it is measured as a result-oriented rather than activity. It was also found that teleworking has a significant relationship with complicatedness of the management and it brings to the negative socio-emotional environment in the work team. Based on the findings, the researcher concluded that unexpected telecommuting in the period of Covid-19 has both
\end{abstract}

\footnotetext{
${ }^{1}$ MBA student, Binary Graduate School, Tashkent Institute of Finance, Tashkent, Uzbekistan

E-mail: fayzievamuyassar87@gmail.com

$2 \mathrm{PhD}$, Assoc. prof., Head of the HRM department, Tashkent State University of Economics, Tashkent, Uzbekistan

E-mail: s.goyipnazarov@tsue.uz

${ }^{3}$ DSc. Prof., Dean of the faculty Economics, Tashkent State University of Economics, Tashkent, Uzbekistan

E-mail: g.abdurarhmanova@tsue.uz
} 
negative and positive impact on employee performance and the entity`s management control.

2181-1415/C 2020 in Science LLC.

This is an open access article under the Attribution 4.0 International (CC BY 4.0) license (https://creativecommons.org/licenses/by/4.0/deed.ru)

\section{COVID-19 пандемияси даврида масофадан ишлашнинг ходимлар мехнат унумдорлиги ва корхонанинг фаолият самарадорлигига таъсирини бахолаш}

Калит сўзлар:

масофадан ишлаш

COVID-19

мехнат унумдорлиги

ходимларнинг фаолияти корхона самардаорлиги

\section{АННОТАЦИЯ}

Ушбу мақолада Ўзбекистонда Covid-19 глобал пандемия шароитида масофадан ишлашнинг ходимларнинг мехнат унумдорлиги ва корхонанинг бошқарувига таъсири қандай эканлиги бахоланган. Covid-19 инқирозининг эпидемиологик ва динамик характери ташкилотларда масофадан ишлаш сиёсатини қабул қилишга мажбур этиши ушубу тадқиқот ишининг ахамиятини оширди. Бу масаланани янада кенгроқ изохлайдиган бўлсак, ушбу эмпирик тадқиқот Ўзбекистонда карантин вақтида ташкилотларнинг масофадан ишлаш жараёнининг иккита мухим жихатини ўрганади. Биринчи холатда, масофадан ишлаш жараёни ходимларнинг мехнат унумдорлиги ва корхона самарадорлигига ижобий таъсир этиши хамда иккинчи холатда эса масофадан ишлаш жараёни корхоналар бошқарув фаолиятини мураккаблаштириши ва нтижада мехнат жамоасининг ижтимоий-рухий мухитига салбий таъсир этишини асослайди. Тадқиқотнинг мақсади масофадан ишлаш жараёни ташкилотнинг хозирги мехнат жараёнларига ижобий ёки салбий таъсир кўрсатадими ёки йўқлилигини аниқлаш хамда Ўзбекистонда кадрларни бошқариш сохасидаги истиқболли мехнат муносабатларини тартибга солишда масафадан ишлаш механизмини такомиллаштириш бўйича тавсиялар беришдан иборатдир. Ушбу мақсадга эришиш учун тадқиқот ишининг структураси тузиб олинди. Олинган маълумотларни тахлил қилишда "Pearson" ўзаро боғликлик коэффициенти хамда тахлил этишнинг миқдорий ва тавсифий усулларидан фойдаланилди. Олинган натижалар шуни кўрсатдики, масофадан ишлаш ходимларнинг мехнат унумдорлиги ва корхонанинг фаолият самарадорлиги билан агар у фаолият жараёни эмас балки, натижага қаратилган бўлса, кучли ва ижобий боғлиқликка эгадир. Бундан ташқари, тадқиқот натижаси масофадан ишлаш жараёнининг корхонанинг бошқарув фаолиятини мураккаблаштириши ва натижада жамоада салбий ижтимоий-рухий мухитини келтириб чиқариши аниқланди. 


\section{Оценка влияния дистанционной производственный труд сотрудников и эффективность предприятия во время пандемии COVID-19 \\ работы на}

\section{Ключевые слова:}

Удаленная работа

COVID-19

Производительность

труда

Эффективность

сотрудников

Эффективность

Предприятия

\section{АННОТАЦИЯ}

В этой статье оценивается влияние удаленной работы в Узбекистане на глобальную пандемию Covid-19 на производительность труда сотрудников и управление предприятием. Эпидемиологический и динамичный характер кризиса Covid-19 вынудил организации принять политику удаленной работы, что повысило важность этого исследования. Вообщем говоря, это эмпирическое исследование исследует два важных аспекта процесса удаленной работы организаций во время карантина в Узбекистане. В первом случае процесс удаленной работы положительно влияет на производительность труда сотрудников и эффективность предприятия, а во втором случае процесс удаленной работы усложняет управление предприятиями и, как следствие, негативно сказывается на социально-психологической среде трудового коллектива. Цель исследования - определить, оказывает ли процесс удаленной работы положительное или отрицательное влияние на текущие рабочие процессы организации и предложить рекомендации по совершенствованию механизма удаленной работы в регулировании перспективных трудовых отношений в Узбекистане. Для достижения этой цели была структурирована структура исследовательской работы. При анализе полученных данных использовались коэффициент корреляции Пирсона, а также количественные и описательные методы анализа. Полученные результаты показали, что удаленная работа имеет сильную и положительную корреляцию с производительностью труда сотрудников и эффективностью предприятия, если это не процесс деятельности, а результативность. Кроме того, исследование показало, что процесс удаленной работы усложняет управленческую деятельность предприятия и, как следствие, создает негативную социальноэмоциональную среду в коллективе.

\section{INTRODUCTION}

While it is not possible to predict accurately the socio-economic damage caused by the global (COVID-19) coronavirus pandemic, economists have a general view that it will have a negative impact on the global economy and living standards. The economic damage caused by the coronavirus pandemic is mainly due to a decline in demand that's to say the lack of consumers to purchase the goods and services available.

According to economists, the severity of the economic impact in this situation largely depends on two factors: the duration of restrictions on human movement and economic 
activity in the country, as well as the actual size and effectiveness of the response to the financial crisis.

Mass quarantine measures in Uzbekistan due to Covid-19 came into force in midMarch 2020. The government approves the procedure for transferring workers to remote mode during the period of quarantine measures by drafting the presidential order "On approval of the Regulation on the temporary procedure for transferring workers to work in remote mode, according to a flexible work schedule or at home during the period of quarantine measures" for organizations. (Registration No. 3228, 03/28/2020). Under the document, during the pendency of the COVID-19 outbreak, employees transferred to this method of work retain the right to receive labour leave, temporary incapacity for work, as well as other rights stipulated by law and a collective agreement.

The global pandemic has led to serious damages in the labour markets of countries. Enterprises of all scales have already been forced to partially or completely cease operations, reduce working hours, switch to a teleworking system, and lay off workers if necessary (S.B.G'oyipnazarov, 2020). In this circumstance, businesses may need to, or choose to, keep workforces remote for several months.

The main purpose of the paper is to study the citizens' (who are working both in private and public sectors) attitudes about teleworking in the condition of COVID-19.

The main objectives of the paper are to identify whether the process of telework affects positively or negatively the organization's current labour processes and propose multiple recommendations regarding to improve the telework mechanism for enabling prospective labour concerns in the human resources field of Uzbekistan.

The most essential part of the quarantine in Uzbekistan is an institution of the teleworking (working from home). Until lockdown in Uzbekistan, only few profession owners worked in teleworking condition, such as accountants, specialists of the information technologies and others. This paper important because of implementation of the teleworking in Uzbekistan is not a wishful event; on the contrary, it happened suddenly. Teleworking is not innovative in nowadays, because of teleworking were studied by plenty of scholars, and therefore I consider that teleworking is significant in the period of COVID-19. Teleworking has several impacts such as increasing labour productivity, the effectiveness of the entity, life satisfaction, happiness and work satisfaction, decreasing conflicts in the work team, absenteeism, employee turnover and etcetera.

Teleworking is currently the work mode of choice for many companies wanting to maintain operations in the face of the new coronavirus pandemic. According to the International Labor Organization (ILO), the number of people working remotely in the world has reached $17.0 \%$ of total employment. In Japan and the United States, the figure is $40.0 \%$.

The share of businesses in Uzbekistan adopting remote working mode has been low, less than $0.5 \%$ of total formal employment. In the country, about 29,000 specialists work at more than 1,400 enterprises in the field of information and communication technologies. However, it has increased suddenly with the COVID-19 shock and the share of this sector in the gross domestic product reached $2.2 \%$. The rapid diffusion of teleworking is not limited to Uzbekistan; it is a worldwide phenomenon.

We could achieve our objectives through a quantitative survey. The quantitative survey was formed and sent to respondents $(n=1200)$ via telegram and in this survey was anonymous. This quantitative survey's main results are: 
-working from the home policy has a strong and positive relationship with employee' labour productivity and the effectiveness of the entity if it is measured as a result-oriented rather than activity;

-multiple recommendations developed taking into account the views of respondents.

The implications of the results are teleworking process affects positively to labour productivity and the effectiveness of the entity. Moreover, teleworking process has a significant relationship with complicatedness of the management and it brings to the negative socio-emotional environment in the work team.

We could know through this empiric research that in the conditions of quarantine and the mandatory transition of most office workers to remote work, the question arises of maintaining the productivity of enterprises and at the same time, the expert noted that the companies and managers at the moment had a critical challenge to organize and control remote work.

The empirical study divided into nine sections: introduction, literature review, objectives, methodology, results, a test of hypotheses, discussion of findings, limitations and future research, recommendations and conclusion.

\section{LITERATURE REVIEW}

\subsection{Introduction}

Teleworking is currently the work mode of choice for many companies wanting to maintain operations in the face of the new coronavirus. According to the International Labor Organization (ILO), the number of people working remotely in the world has reached $17.0 \%$ of total employment. In Japan and the United States, the figure is $40.0 \%$.

The share of businesses in Uzbekistan adopting remote working mode has been low, less than $0.5 \%$ of total formal employment. In the country, about 29,000 specialists work at more than 1,400 enterprises in the field of information and communication technologies. However, it has increased suddenly with the COVID-19 shock and the share of this sector in the gross domestic product reached $2.2 \%$. The rapid diffusion of teleworking is not limited to Uzbekistan; it is a worldwide phenomenon.

So far, several scholars such as Fintan Clear and Keith Dickson, 2005; Marja Coenon and Robert A.W. Kok, 2013; Bianca A.C. Groen at al., 2018; Alan Felstead at al,, 2003; Timothy D. Golden, 2006; HongGirl Lee, 2007; Manuela Perez Perez at al., 2005; Sachiko Kazekami, 2019; M.P. Perez, 2002; Lubica Bajzikova, 2016, and others have conducted researches either empiric or theoretical aspect.

Managerially, organizations wishing to implement telework should start by shaping the attitude of its management towards a favourable perception. Adopting a teleworking program changes communication patterns, performance management relationships, corporate culture and potentially the work itself (Watad and Will, 2003). Implementation of employee telework perceived mostly as an employee's informal benefit with a potentially positive impact on his/her increased productivity and satisfaction. On the other hand, it frequently considered an alternative to the traditional work arrangement with the employee working from home without the employer's necessity to settle his/her overtime (Lubica Bajzikova, 2016).

Furthermore, Erica Israelson (2001) investigated that the amount of time, individuals spend teleworking positively related to overall job satisfaction, and this relationship mediated by perceived autonomy on the job. 


\subsection{Teleworking}

Telework - also commonly known as telecommuting -originally often defined as working away from a traditional office or at home (Daniels. K. at al., 2001). Teleworking can take place from a remote office, from home or during transportation. The majority (89\%) of teleworkers work at home (Vega, 2003). The development of teleworking started in the 1970s but the number of teleworkers was initially very low due to a combination of technological limits and high costs in the information and communication technologies at that time, companies reluctance and unions opposition. In the early 1990s, teleworking was again rediscovered as an alternative way to organize work to reduce commuting, balance work and family, and obtain other economic and social advantages, all of which lead to a growing diffusion of teleworking among industrial and service companies (Venkatesh. V., 2000).

Telework is increasingly becoming an integral part of organizational design. It has the potential to benefit firms in various manners as we are entering the knowledge society (HongGirl Lee at al., 2007). The degree of telework was found to be positively related to organizational commitment and negatively related to turnover intentions, such that a higher degree of teleworking is associated with more commitment to the organization and weakened turnover intentions (Timothy D. Golden, 2006). Teleworkers' dual response for both telework and central work situations could have biased their judgment. The justification was that teleworkers also reported to the central office and accordingly could offer balanced inputs on the studied variables. To avoid the possibility of common method bias, however, future studies can gather survey responses separately from teleworkers and non-teleworkers (HongGirl Lee at al., 2007). Telework provides needed flexibility in a unique way that provides a win-win for all (Debra A. Major at al., 2008).

Homeworking can be the perfect solution to the search for a balanced and fulfilling quality of life - yielding improvements in performance, stress levels, and family life (Yehuda Baruch and Nigel Nicholson, 1997).

According to the International Labor Organization, various types of teleworking available in the labour relations: regular home-based telework, high mobile telework, occasional telework. These types of teleworking shown in Table 1.

Table 1.

Types of telework

\begin{tabular}{|c|c|c|}
\hline Modality & Use of Technology & Location \\
\hline $\begin{array}{c}\text { Regular home-based } \\
\text { telework }\end{array}$ & $\begin{array}{c}\text { Always or almost all the } \\
\text { time }\end{array}$ & $\begin{array}{c}\text { From home at least several times a } \\
\text { month and in other locations less often } \\
\text { than several times a month. }\end{array}$ \\
\hline High mobile telework & $\begin{array}{c}\text { Always or almost all the } \\
\text { time }\end{array}$ & $\begin{array}{c}\text { At least several times a week in at } \\
\text { least two locations other than the } \\
\text { employer's premises or working daily } \\
\text { in at least one other location. }\end{array}$ \\
\hline Occasional telework & $\begin{array}{c}\text { Always or almost all the } \\
\text { time }\end{array}$ & $\begin{array}{c}\text { Less frequently and/or fewer } \\
\text { locations than high T/lCTM }\end{array}$ \\
\hline
\end{tabular}

Source: Eurofound and the International Labour Organization (ILO)

Telework is to a large extent an instrument that alters the organization's competencies, through the practice's effects on a variety of resource domains, and by 
identifying these various effects, a firm can engage in more rational strategic planning (Viviane Illegems and Alain Verbeke, 2004).

Managers with experience in telework adoption recognize a variety of long-run, strategic impacts on their organization's resource-base. Telework is to a large extent an instrument that alters the organization's competencies, through the practice's effects on a variety of resource domains, and by identifying these various effects, a firm can engage in more rational strategic planning. In contrast, managers in organizations that have not implemented telework expect a lower level of strategic benefits. An in-depth evaluation of expected telework effects on the organization's various affected resource domains, beyond immediate effects on the bottom-line, appears critical in explaining why managers adopt or reject telework (Viviane Illegems and Alain Verbeke, 2004).

Teleworking adoption will be then greater among organizations that enhance innovation and change. Managers who want to adopt teleworking may facilitate the process through an innovation culture that supports and encourages technological and organizational innovations. ...that teleworking adoption facilitated if the firm is innovation-intensive, mainly in organizational innovations, which supports other studies that consider teleworking adoption to be easier after an organizational change in the firm (Daniels. K. at al., 2001). A greater pool of technological, organizational and human resources may increase the probability to adopt teleworking (Manuela P. Perez at al., 2005). Teleworking firms are more aware and knowledgeable about teleworking experiences and issues before adoption (Manuela P. Perez at al., 2005). Those companies with employee training programmes perceived lower barriers to telework adoption. The variance of telework barriers better explained by technological factors than by Human Resource factors (Manuela P. Perez at al., 2002).

Kerry Harman (2003) studied and found that in the development of a manager teleworker relationship in a telework setting with the spotlight directly placed on the teleworker. The teleworker and their manager operate two synchronous work relationships - the working relationship in the telework setting and the working relationship in the co-located setting. The dynamics found in the telework relationships in this study are related to the teleworker and their manager learning how to relate to each other within these dual work relationships (Kerry Harman, 2003).

Jill L. Swisher (2019) found that employers can now consider whether requiring face time is as imperative as once thought and can consider instead of effective leadership and communication strategies when implementing or maintaining sustainable telework programs.

\subsection{Teleworking in the Covid-19 condition}

Angel Belzunegui-Eraso and Amaya Erro-Garcés (2020) studied that extant experience related to the management of the Covid-19 situation in firms across European and Asian countries indicate that companies from the service sector, and, in particular, telematics leisure businesses, energy companies, insurance businesses, banking services, and technology companies are the industries that present higher rates of telework implementation. Moreover, these researchers identified that this exceptional situation ends, employees will keep their economic rights. Monitoring this return to the previous pre-crisis situation will be interesting in terms of observing if these rights are maintained or if given the exceptionality and if the pandemic results in a chronic situation or 
reappears in the short-term, these rights are reduced. Table 3 describes the economic rights of the employees.

Table 3.

Telework requirements before and during the Covid-19 crisis.

\begin{tabular}{|l|c|c|}
\hline Collective Agreements Considerations & $\begin{array}{c}\text { Before the } \\
\text { Covid-19 Crisis }\end{array}$ & $\begin{array}{c}\text { During the } \\
\text { Covid-19 Crisis }\end{array}$ \\
\hline Voluntary character & Yes & No \\
Individual agreement & Yes \\
Reversibility & Yes & No \\
Equality of rights between teleworkers and workers & Yes \\
at the employers' premises & & \\
Work equipment facilitation and installation & Yes & Software only \\
Ergonomic elements & Yes & No \\
Technical support & Yes & Yes \\
Costs of telework & If required & If required \\
Health, social security and job security & Yes & No \\
Right to union representation & Yes & Yes \\
In-company training & Yes & Yes \\
Preservation of economic conditions & Yes & Yes \\
Modifications in the statute of rights for workers & No & No \\
\hline
\end{tabular}

Baert, Stijn at al. (2020) found that employees who are more dependent on others in their job encounter more negative consequences from extended telework due to the COVID-19 crisis. In particular, during this period of extended telework, they report more conflicts with colleagues and family, are more disturbed by roommates, and have a harder time combining the different means of communication available to them. This lower satisfaction with extended telework is also the case for respondents used to receiving a lot of feedback, as well as those used to a lot of interaction outside their organisation and those who have already experienced high levels of job autonomy.

Pauline E.Onyeukwu at al. (2020) studied that online teaching has a significant effect on social distancing. Nowadays, there is continuous and ever-increasing demand by customers for the use of remote activities to curb the spread of COVID-19. This is because stakeholders are increasingly becoming aware of the benefits of telecommuting in the educational sector.

\section{OBJECTIVES}

This research consists of two main objectives:

-to identify whether the process of telework affects positively or negatively the organization's current labour processes;

-to propose multiple recommendations regarding to improve the telework mechanism for enabling prospective labour concerns in the human resources field of Uzbekistan. 


\section{METHODOLOGY}

\subsection{Overview}

The research was exploratory in nature and the research method was used to complete it. The researchers preferred of the survey-quantitative research strategy. While teleworking, its impact to labour productivity or the effectiveness of the entity, whether teleworking complicates the management activities or not, its effects to the socio-emotional environment in the work teams have been investigated in previous researches by scholars, however, we want to emphasize that the effects of teleworking to the labour concerns of Uzbekistan were studied the first time. The purpose of this research is to study the peoples' attitudes of Uzbekistan about teleworking in the period of COVID-19. During COVID-19, employees and employers in Uzbekistan stayed at homes and for this reason, the research survey questionnaire sent to respondents' profiles via telegram program.

\subsection{Research questions and hypotheses}

This research investigates whether there is a significant relationship between teleworking and employee' labour productivity, the effectiveness of entity, management activities, the socio-emotional environment in the work team. The specific research questions to be investigated in this study are:

-Does teleworking effect positively employee' labour productivity and the effectiveness of the entity?

-Does teleworking complicate the management activities and effect negatively the socio-emotional environment in the work team?

\subsection{Research design}

The responses of the respondents' were collected at one time and for this reason, this research is based on a cross-sectional design. This research is exploratory in nature and the research method is a survey method.

In view of the above, during the study, the situation of teleworking ant its impact on organizational performance in some organizations operating in Uzbekistan was studied on the basis of a survey method. This survey was based on the Likert scale. According to this method, the answers to 2 questions based on 5 parameters (dimensions) are formed in the following order: "5" - strongly agree, "4" - agree, "3" - not sure, "2" - do not agree, "1" completely disagree.

The organization of the research includes the following stages: organizational (preparatory); the process of organizing the survey; the stage of processing the obtained results; preparation of conclusions on the basis of results and development of offers and recommendations on improvement of the activity.

The validity and reliability of the survey options based on the Likert scale are based on an assessment of its internal stability. IBM SPSS Statistics 22.0 used Cronbach's alpha coefficient to assess the internal stability of the questionnaire and the reliability of the internal compatibility.

\subsubsection{Dependent variables}

The dependent variables for the study are the four the following variables:

-employee' labor productivity;

-effectiveness of entity;

-management activity;

-socio-emotional environment. 


\subsubsection{Independent variable}

The independent variable for the study is one variable:

-teleworking.

\subsubsection{Population and sampling}

The population for this study is defined as all employees and employers who work at the private and public business entities and organizations in Uzbekistan in the period of COVID-19. The respondents $(n=1200)$ were identified randomly and the sample size our research is 1200 employees and employers.

\subsubsection{Data collection instrument and data collection.}

The research survey was created on the Likert scale wherewith via Telegramprogram. The survey consisted of two questions and ten items and the survey was sent to respondents' social network profiles (Telegram). The population of the survey was one thousand two hundred (1200).

\section{RESULTS}

As a result of the analysis, Cronbach's alpha coefficient is between 0 and 1 , and if its value is $a \geq 0.9$, then the internal stability of the results from each survey is "excellent", if $a \geq 0.8$, "good", if a $\geq 0.7$,"acceptable", if a $\geq 0.6$, it is "suspicious" and finally, if a $\geq 0.5$, it is "unacceptable". In our study, it was found that this coefficient was 0.85 . This means that the statistical reliability of the study is positive. The reliability statistics are described in Table 1.

Table 1.

Reliability statistics

\begin{tabular}{|c|c|}
\hline Cronbach's Alpha & Number of items \\
\hline 0.85 & 4 \\
\hline
\end{tabular}

Table 2 and Table 3 present the answers of the respondents to the questionnaire were analyzed, their average statistical value and frequency of responses were calculated and reflected in the results.

Table 2.

Teleworking positively affects employee' labor productivity and the effectiveness of entity

\begin{tabular}{|c|c|c|c|c|}
\hline No & Options & Frequency & Percentage & $\begin{array}{c}\text { Mean } \\
(\mathbf{x})\end{array}$ \\
\hline 1 & Strongly disagree & 140 & 12 & \\
\hline 2 & Disagree & 160 & 13 \\
\hline 3 & Neutral & 150 & 12 & \multirow{3}{*}{3.6} \\
\hline 4 & Agree & 390 & 33 & \\
\hline 5 & Strongly agree & 350 & $\mathbf{1 0 0}$ & \\
\hline
\end{tabular}

From Table 2, the total which captures several respondents was 1200 . This means that 1200 out of the 1200 sample size validly participated in the questionnaire. Focusing on the research question herein, $12 \%$ and $13 \%$ of the valid respondents strongly disagreed and disagreed respectively that arrangement that teleworking positively 
affects employee' labour productivity and the effectiveness of the entity. Another $12.0 \%$ of respondents remained neutral and had shown themselves as if they were not sure of the problem. On the other hand, $33.0 \%$ and $30.0 \%$ of the respondents agreed and strongly agreed that arrangement that teleworking positively affects employee' labour productivity and the effectiveness of entity in the condition of global pandemic COVID-19. The result obtained from data analysis indicates that more than half of the respondents agreed that arrangement that teleworking positively affects employee' labour productivity and the effectiveness of the entity. In the same way, the statistical value for the variables was $\mathrm{x}=3.6$ as given in Table 2 . Here $\mathrm{x}$ is close to 4 means in a five-point Likert scale method of analysis, therefore it is considered as 4 . This means that the study participants agreed that arrangement that teleworking positively affects employee' labour productivity and the effectiveness of the entity. The results indicated that working from the home policy has a strong and positive relationship with employee' labour productivity and the effectiveness of the entity if it is measured as a result-oriented rather than activity.

Table 3.

Teleworking complicates the management activities and affects negatively the socio-emotional environment in the work team

\begin{tabular}{|c|c|c|c|c|}
\hline № & Options & Frequency & Percentage & $\begin{array}{c}\text { Mean } \\
\text { (x) }\end{array}$ \\
\hline 1 & Strongly disagree & 104 & 9 & \multirow{6}{*}{3.7} \\
\hline 2 & Disagree & 159 & 13 & \\
\hline 3 & Neutral & 144 & 12 & \\
\hline 4 & Agree & 450 & 36 & \\
\hline 5 & Strongly agree & 340 & 28 & \\
\hline & Total & 1200 & 100 & \\
\hline
\end{tabular}

From Table 3, 9\% and $13.0 \%$ of the validly sampled 1200 respondent strongly disagreed and disagreed respectively that arrangement that teleworking complicates the management activities and affects negatively the socio-emotional environment in the work team. Alternatively, 36\% and $28 \%$ of the respondents agreed and strongly agreed respectively that arrangement that teleworking complicates the management activities and affects negatively the socio-emotional environment in the work team. This shows that most of the respondents accepted that arrangement that working in telework mode brings to the problems in micromanagement and negative socio-emotional mood between employees in the organizations. Then again, the mean of 3.7 was higher than the cut-off mean for acceptance of 3.00 for a five-point Likert scale; this suggests that the mean should be accepted. Therefore, since the mean was higher than the cut-off mean, the study submits that the arrangement that teleworking significantly relates to the complicatedness of the management and negativity of socio-emotional environment of the working team. 


\section{TEST OF HYPOTHESES}

For making sure for reliability of the key findings of the research, the study conducted hypotheses test and the results presented below:

\subsection{Hypothesis One}

The hypotheses presented below stated in both the Alternative and Null forms.

Table 4.

Pearson correlation result for the relationship between arrangement that teleworking and employee' labor productivity and the effectiveness of entity

\begin{tabular}{|c|c|c|c|}
\hline Variables & $\begin{array}{c}\text { Pearson correlation } \\
\text { coefficient }\end{array}$ & Probability values & N \\
\hline $\begin{array}{c}\text { Independent variable: } \\
\text { Teleworking }\end{array}$ & 0.95 & 0.02 & 1200 \\
\hline
\end{tabular}

Table 4 shows the relationship between the arrangements that teleworking and employee' labour productivity and the effectiveness of the entity. Question number 3 in the questionnaire was used as the dependent variable while question number 1 was used as the independent variable. The Pearson correlation coefficient for the relationship between the arrangements that teleworking and employee' labour productivity and the effectiveness of the entity was 0.95 . This indicates that the relationship between arrangements that teleworking and employee' labour productivity and the effectiveness of the entity was strong and positive. On the other hand, the probability value (p-value) of 0.02 was less than the 0.05 maximum significance value for significance. This shows that the relationship between arrangements that teleworking and employee' labour productivity and the effectiveness of the entity was positive. Based on these, the research rejected the null hypothesis, accepted the alternative and concludes that arrangement that teleworking has a positive relationship with employee' labour productivity and the effectiveness of the entity.

\subsection{Hypothesis Two}

Table 5.

Pearson correlation result for the relationship between arrangement that teleworking and management activities of entity and socio-emotional environment in the work team

\begin{tabular}{|c|c|c|c|}
\hline Variables & $\begin{array}{c}\text { Pearson } \\
\text { correlation } \\
\text { coefficient }\end{array}$ & Probability values & N \\
\hline $\begin{array}{c}\text { Independent variable: } \\
\text { Teleworking }\end{array}$ & 0.09 & 0.20 & 1200 \\
\hline
\end{tabular}


Table 5 emphasizes the Pearson correlation result for the arrangement that teleworking has no positive relationship with the management activities of the entity and socio-emotional environment in the work team. From Table 5 the study used question number 4 in the questionnaire as the dependent variable and question number 1 in the questionnaire as the independent variable. In a specific term, the Pearson correlation coefficient was 0.09 . This indicates a weak relationship and implies that the relationship between arrangements that teleworking to management activities of an entity and socioemotional environment in the work team was weak but positive. In the same way, the probability value ( $p$-value) of 0.20 was higher than the 0.05 maximum significance value for significance. This indicates that the relationship was not significant. Therefore, the study accepts the null hypothesis and concludes that arrangement that teleworking has no significant relationship with management activities of an entity and socio-emotional environment in the work team.

\section{DISCUSSION OF FINDINGS}

By testing of the first hypothesis, it was known that the arrangement that teleworking has a positive relationship with employee' labour productivity and the effectiveness of entity if it is measured as a result-oriented rather than activity. This supports the finding of the study carried out by OCED researchers (2020), which revealed that telework can improve or hamper firm performance, with its overall effect depending importantly on two main channels: A direct channel affects firm performance through changing the efficiency, motivation and knowledge creation of the workforce; an indirect channel is for telework to facilitate cost reductions that free up resources for productivity-enhancing innovation and reorganization.

The test of the second hypothesis revealed that arrangement that teleworking has a weak and no significant relationship with the management activities of the entity and the socio-emotional environment in the work team. This also supports of the findings of Maria Charalampous, Christine A. Grant, Carlo Tramontano and Evie Michailidis (2019), which revealed that there are some negative aspects of telecommuting which are highlighted within this review; such as social and professional isolation and perceived threats in professional advancement.

\section{LIMITATIONS AND FUTURE RESEARCH}

There is a limitation that we investigated only a few variables in the two research questions about whether teleworking effects or not to the labour relations regarding on the issues of the organization and employee extent (employee' labour productivity, the effectiveness of entity, management activities of the entity, and socio-emotional environment in the work team). However, this research does not highlight deeply aspects of the teleworking process and benefits of the organizations and employees. Future researches may be conducted with the following variables: information and communication technologies, telework adoption, teleworking skills, advantages of telework, managing telework, saving costs, decreasing employee turnover, decreasing staff conflicts, organizational performance, saving work travel time, balancing work and family issues, flexible work schedules, workplace flexibility, life satisfaction, job satisfaction, interruption at work, interpersonal relationship and etcetera. 


\section{RECOMMENDATIONS AND CONCLUSION}

The study has shown that teleworking has a positive relationship with employee' labour productivity and the effectiveness of the entity. So, to aim to implementation of the teleworking broadly extend and understandable, there should be several changes in the labour legislation of Uzbekistan regarding for legal and true activities of the executives and personnel staff in the organizations (both, private and public).

The next important finding is teleworking has a weak and no significant relationship with management activities of an entity and the socio-emotional environment in the work team. The use of telework as a response to the crisis and for business continuity depends on the activity of the organization, and it is heterogeneous among activities. Therefore, this means that there are also other variables capable of improving the management control and socio-emotional environment among the working team. In this case, mechanism and a system for the effective implementation of teleworking in the activities of the organizations should be developed by the relevant specialists for regulating the relationship between manager-employee and among employees during Covid-19 and after this phenomenon. We consider that if the following references are accounted in the mechanism, it will be possible to implement the teleworking mechanism in a short time period and effectively in the organization's activities:

- Developing of the list about organizations and entrepreneur subjects that have access to teleworking process;

- Creating of the instructions in the teleworking mechanism regarding how managers and employees are involved in the teleworking process and the benefits of teleworking for managers-employees and organizations (for example, management control, management activities, interactions between managers and employees in the teleworking condition, increasing labour productivity, decreasing employee turnover, decreasing of the absenteeism, collective agreement considerations during teleworking process, interactions between employees in the teleworking condition, flexible work schedule, achieving a balance between work and family issues, decreasing conflicts among employees, increasing sense of life and job satisfaction, absence of overtime work, decreasing work travel time, health and safety issues, and etcetera;

- Giving them information about tips for both managers and employees under teleworking condition (for instance, managers should focus results of the activity, not management activities, how managers can saving costs, establishing training courses regarding using of information communication technologies and working under teleworking condition, using different communication tools between organization and clients, businesses, employees and etcetera);

- Providing soft bank credits to small and medium-sized enterprises for supporting them in the transition into the teleworking process (for example, buying ICT devices, connecting internet network, providing adequate equipment and resources, and etcetera);

- Placing regular research orders by the Ministry of employment and labour relations of the Republic of Uzbekistan regarding how telework process affects the labour issues of the country. 


\section{REFERENCES}

1. Aguilera, A., Lethiais, V., Rallet, A., Proulhac, L., (2016). “Home-based telework in France: Characteristics, barriers and perspectives", Transportation Research Part A 92 (2016) 1-11.

2. Alvesson, M., Sveningsson, S., (2003). “Good Visions, Bad Micro-management and Ugly Ambiguity: Contradictions of (Non-) Leadership in a Knowledge-Intensive Organization", European Group for Organizational Studies 2003 24: 96, D0I: 10.1177/0170840603024006007

3. Baruch, Y., Nicholson, N., (1997). "Home, Sweet Work: Requirements for effective Home Working", Journal of General Management, Vol. 23 No. 2 Winter 1997.

4. Baruch, Y., (2000). "Teleworking: benefits and pitfalls as perceived by professionals and managers", New Technology, Work and Employment 15:1.

5. Baert, S., Lippens, L., Moens, E., Sterkens, P., Weytjens, J., (2020). “The COVID-19 crisis and telework: A research survey on experiences, expectations and hopes", GLO Discussion Paper, No. 532, Global Labor Organization (GLO), Essen.

6. Bajzikova, L., Sajgalikova, H., Wojcak, E., Polakova, M., (2016). "How Far Is Contract and Employee Telework Implemented in SMEs and Large Enterprises?", Procedia - Social and Behavioral Sciences 235 (2016) 420-426.

7. Belzunegui-Eraso, A., Erro-Garcés, A., (2020). "Teleworking in the Context of the Covid-19 Crisis", Sustainability 2020, 12, 3662.

8. Braun, I., Schill, A., (1999). "Experiences with Regional Teleworking Support for Small and Medium-sized Enterprises", 1st Regional Telematics Conference, Session No. 5b Tanum, 16th June 1999.

9. Charalampous, M., Grant, Ch. A., Tramontano, C., \& Michailidis. E., (2019). "Systematically reviewing remote e-workers' well-being at work: a multidimensional approach", European Journal of Work and Organizational Psychology, 28:1, 51-73, DOI: 10.1080/1359432X.2018.1541886

10. Clear, F., Dickson, K., (2005). "Teleworking Practice in Small and medium-Sized Firms: Management Style and Worker Autonomy", New Technology, Work and Employment, 20 (3):218-229, Nov 2005.

11. Coenen, M., Kok, R. A. W., (2014). "Workplace flexibility and new product development performance: The role of telework and flexible work schedules", European Management Journal (2014), http://dx.doi.org/10.1016/j.emj.2013.12.003

12. Crosbie, T., Moore1, J., (2004). "Work-life Balance and Working from Home", Social Policy \& Society 3:3, 223-233, DOI:10.1017/S1474746404001733

13. Dambrin, C., (2004). "How does telework influence the manager-employee relationship?", International Journal Human Resources Development and Management, Vol. 4, No. 4, pp.358-374.

14. Daniels, K., Lamond, D., Standen, P., (2001). “Teleworking: frameworks for organizational research", Journal of Management Studies, 38(8), 1151-1185.

15. Desrosiers, E. I., (2001). "Telework and Work Attitudes: The Relationship Between Telecommuting and Employee Job Satisfaction, Organizational Commitment, Perceived Organizational Support, and Perceived Co-worker Support", Open Access Dissertations, https://docs.lib.purdue.edu/open_access dissertations/1511 
16. Di Domenico, L., Pullano, G., Coletti, P., Hens, N., Colizza, V., (2020). "Expected impact of school closure and telework to mitigate COVID-19 epidemic in France", Report \#8, www.epicx-lab.com/covid-19.html

17. Duxbury, L., Neufeld, D., (1999). "An empirical evaluation of the impacts of telecommuting on intra-organizational communication", Journal of Engineering and Technology Management 16 (1999) 1-28.

18. Felstead, A., Jewson, N., Phizacklea, A., Walters, S., (2001). "Working at home: Statistical Evidence for Seven Key Hypotheses", Work, Employment\&Society, Vol.15, No.2, pp.215-231.

19. Felstead, A., Jewson, N., Walters, S., (2003). "Managerial Control of Employees Working at Home", British Journal of Industrial Relations 41:2 June 2003 0007-1080 pp. 241-264.

20. Forgacs, T., (2010). "Empirical research findings on telework: Management experiences and attitudes", BEH - Business and Economic Horizons, Volume 1| Issue 1| April 2010 |pp. 6-13, www.pieb.cz

21. Goyipnazarov S. ПАНДЕМИЯ ШАРОИТИДА ГЛОБАЛ ИҚТИСОДИЁТ ВА АХОЛИНИНГ ТУРМУШ ДАРАЖАСИГА ТАЪСИР КЎРСАТУВЧИ ОМИЛЛАР //АрХИВ научных исследований. - 2020. - №. 10.

22. Golden, T., D., (2006). "Avoiding depletion in virtual work: Telework and the intervening impact of work exhaustion on commitment and turnover intentions", Journal of Vocational Behavior 69 (2006) 176-187.

23. Groen, B. A. C., Triest, S. P., Coers, M., Wtenweerde, N., (2018). "Managing flexible work arrangements: Teleworking and output controls", European Management Journal, https://doi.org/10.1016/i.emj.2018.01.007

24. Harman, K., (2003). "An exploration of teleworker - manager work relationships in telework settings", Masters thesis, University of New South Wales.

25. Helminen, V., Ristimaki, M., (2007). "Relationships between commuting distance, frequency and telework in Finland", Journal of Transport Geography 15 (2007) 331-342, doi:10.1016/j.jtrangeo.2006.12.004

26. Hunton, J. F., Ken Harmon, W., (2004). "A model for investigating telework in accounting", International Journal of Accounting Information Systems 5 (2004) 417-427.

27. Huws, U., (1991). "TELEWORK: PROJECTIONS", FUTURES January/February 1991

28. Illegems, V., Verbeke, A., (2004). "Telework: What Does it Mean for Management?", Long Range Planning 37 (2004) 319-334, doi:10.1016/j.lrp.2004.03.004

29. Karia, N., Asaari, M.H.A.H., (2016). "Innovation capability: the impact of teleworking on sustainable competitive advantage", International Journal Technology, Policy and Management, Vol. 16, No. 2, pp.181-194.

30. Kazekami, S., (2019). "Mechanisms to improve labor productivity by performing telework", Telecommunications Policy, https://doi.org/10.1016/j.telpol.2019.101868

31. Kenley, R., (2004). "PROJECT MICROMANAGEMENT: PRACTICAL SITE PLANNING AND MANAGEMENT OF WORK FLOW", https://www.researchgate.net/publication/252208615. 
32. Lee, H., Shin, B., Higa, K., (2007). "Telework vs. central work: A comparative view of knowledge accessibility", Decision Support Systems 43 (2007) 687-700, doi:10.1016/j.dss.2006.11.007.

33. Levin, R. P., (2016). "The micromanagement trap", JADA 147 http://jada.ada.org April 2016.

34. Limburg, D., Jackson, P. J., (2008). "Performance Management for Teleworking: the Role of Workflow Management Systems", Article in Journal of E-working, January 2008, https://www.researchgate.net/publication/26549739.

35. Mahler, J., (2012). "The Telework Divide: Managerial and Personnel Challenges of Telework", Review of Public Personnel Administration XX (X) 1 -12, DOI: 10.1177/0734371X12458127, http://rop.sagepub.com.

36. Major, D. A., Verive, J. M., Joice, W., (2008). "Telework as a Dependent Care Solution: Examining Current Practice to Improve Telework Management Strategies", The Psychologist-Manager Journal, 11: 65-91, DOI: 10.1080/10887150801967134.

37. Nicholas, A. J., (2016). "Management and Telework", Faculty and Staff - Articles \& Papers. 60. https://digitalcommons.salve.edu/fac staff pub/60.

38. OECD Policy Responses to Coronavirus (COVID-19). Productivity gains from teleworking in the post COVID-19 era: How can public policies make it happen? (C) OECD 2020.

39. Onyeukwu, P. E., Adeniyi, A., Amin, H. J., (2020). "Telecommuting: A Panacea to COVID-19 Spread in Nigerian Universities", International Journal of Innovation and Economic Development, http://dx.doi.org/10.18775/ijied.1849-75517020.2015.61.2004.

40. Perez, M. P., Sanchez, A. M., de Luis Carnicer, M. P., Vela Jimenez, M. J., (2007). "Telework, human resource flexibility and firm performance", New Technology, Work and Employment 22:3.

41. Perez, M. P., Sanchez, A. M., de Luis Carnicer, M. P., Vela Jimenez, M. J., (2005). "The differences of firm resources and the adoption of teleworking", Technovation 25 (2005) 1476-1483.

42. Petersa, P., Tijdensb, K. G., Wetzelsc, C., (2004). “Employees' opportunities, preferences, and practices in telecommuting adoption", Information \& Management 41 (2004) 469-482, doi:10.1016/S0378-7206(03)00085-5.

43. Sanchez, A. M., Perez, M. P., de Luis Carnicer, M. P., (2002). "Benefits and barriers of telework: perception differences of human resources managers according to company's operations strategy", Technovation 22 (2002) 775-783.

44. Silva-C, A., Montoya R, I. A., Valencia A, J. A., (2019). "The attitude of managers toward telework, why is so difficult to adopt it in organizations?", Technology in Society 59 (2019) 101133, https://doi.org/10.1016/i.techsoc.2019.04.009.

45. Skyrme, D. J., (1994). "Flexible Working: Building a Lean and Responsive Organization", Long Range Planning Vol. 27, No 5, pp. 98-110.

46. Stanworth, C., (1996). "Telework and Human Resource Management", The Institution of Electrical Engineers.

47. Swisher, J. L., (2019). "Telecommuting and its associations with job satisfaction: going the extra mile", A Dissertation, Concordia University Library, www.cui.edu/library. 
48. Turetken, O., Jain, A., Quesenberry, B., Ngwenyama, O., (2011). “An Empirical Investigation of the Impact of Individual and Work Characteristics on Telecommuting Success", IEEE Transactions On Professional Communication, Vol. 54, No. 1, March 2011.

49. Vega, G., (2003). "Managing Teleworkers and Telecommuting Strategies", Westport, Connecticut: Praeger.

50. Venkatesh, V., (2000). "Creating an effective training environment for enhancing telework", International Journal Human-Computer Studies 6, 991-1005.

51. Watad, M., Will, P., (2003). "Telecommuting and Organizational change: A Middle-Managers' Perspective”, Business Process Management Journal 9, 4, 459-472.

52. Wojcak, E., Bajzikova, L., Sajgalikova, H., Polakova, M., (2016). "How to Achieve Sustainable Efficiency with Teleworkers: Leadership Model in Telework", Procedia Social and Behavioral Sciences 229 (2016) 33 - 41, doi: 10.1016/j.sbspro.2016.07.111.

53. Исамухамедов $\quad$ Б., Исамухамедова Д. Стратегические направления управления системой подготовки кадров экономистов //InterConf. - 2020.

54. Зокирова Н. К., Абдурахманова Г., Сагидуллин Ф. Р. Трансформация форм занятости в инновационном развитии //International scientific review. - 2020. - №. LXX.

55. Абдурахманова Гулнора Каландаровна, Рустамов Достонбек Жамшид Угли. Достойный труд в системе политики занятости // International scientific review. 2019. №LXVII. URL: https://cyberleninka.ru/article/n/dostoynyy-trud-vsisteme-politiki-zanyatosti (дата обращения: 19.06.2020).

56. Goyipnazarov S. ASSESSMENT OF OCCUPATIONAL SAFETY MEASURES IN SMALL BUSINESSES //ISJ Theoretical \& Applied Science. - 2018. - T. 6. - №. 62. - C. 207212.

57. Goyipnazarov S. ОЦЕНКА МЕР БЕЗОПАСНОСТИ ТРУДА В МАЛЫХ ПРЕДПРИЯТИЯХ //Theoretical \& Applied Science. - 2018. - №. 6. - С. 207-212. 